\title{
Strategi Dakwah Jamaah Tabligh dalam Tazkiyat Al-Nafs di Masjid PP. Darul Ulum Pakes Desa Panaan Palengaan Pamekasan
}

\author{
Moh Ruji ${ }^{*}$, Abdul Hadi Faisol ${ }^{2}$ \\ ${ }^{1}$ Bimbingan Penyuluhan Islam, IAI Miftahul Ulum Pamekasan \\ ${ }^{2}$ Bimbingan Penyuluhan Islam, IAI Miftahul Ulum Pamekasan \\ *e-mail:mohruji@gmail.com
}

\begin{abstract}
Abstrak: Strategi dalam penjelankan sebuah dakwah adalah sebuah cara yang dilakukan agar dakwah yang disampaikan dapat diterima oleh masyarakat. Strrategi dakwah Jamaah Tabligh dalam hal Tazkiyat Al-nafs yaitu melalui kegiatan atau tindak lanjut dari setiap yang telah direncanakan sebelumnya selama masa tiga hari program berjalan.Metode yang digunakan penulis adalah metode Deskriptif kualitatif, yaitu dengan cara melalui pengamatan lapangan, wawancara, dan dokumentasi dari Jamaah Tabligh. Tujuan dari penelitian ini untuk mengetahui stragegi dakwah yang dilakukan oleh Jama' Tabligh, faktor pendukung dan penghambat serta solusinya. Hasil penelitian. Pertama berisi tentang penyampaian terima kasih dan permohonan maaf dengan mesyarakat atas kesalahan selama beriktikaf di masjid, dan mengajak masyarakat untuk bergabung aktif dalam program khuruj (tasykil) demi tercapainya jiwa yang bersih (Tazkiyat Al- nafS). Bagi kaum perempuan para Da'I mendatangi rumahnya dan membacakan Taklim. Meberi bantuian bagi yang tidak mampu dalam bidang ekonomi bagi yang ingin hendak melakukan Khuruj dan membantu sebagian pekerjaan rumahnya selama ia Khuruj. Di sinalah salah satu kunci strategi yang dapat memikat para hati mad'u untuk dapat diajak bergabung dalam kegiatan dakwah Jamaah Tabligh sehingga dapat mengamalkan dan bisa menyampaiakan kepada orang lain. Bagi Masyarakat yang berkeinginan Khuruj (keluar) namun sibuk, maka tugas tersebut di tanggung sebagian anggota Jamaah Tabligh yang kebetulan tidak melaksanakan Khuruj.
\end{abstract}

Kata kunci: strategi dakwah; jamaah tabligh; tazkiyat al nafs.

\section{PENDAHULUAN}

Munculnya indikasi keberagaman dan kesalehan sosial masyarakat akhir-akhir ini ternyata juga memunculkan sesuatu yang tidak ideal. Dengan melihat maraknya aliran-aliran. Dan maraknya dakwah namun kenyataannya belum mampu menahan masuknya beberapa ajaran atau pemahaman yang belum relevan ${ }^{1}$. Lebih-lebih di era modernisasi saat ini, Umat islam tengah berada di pusaran globalisasi dunia yang dapat menyeret pada kemiskinan identitas. berbagai bentuk serangan tertuju pada ummat islam, mulai dari perbedaan persepsi, interpretasi, atau ekspresi keagamaan dan pada tingkat tertentu akan menimbulkan adanya aliran-aliran keagamaan lain, atau mulai dari maneuver adat, budaya dan kebiasaan bangsa luar, telah masuk kesetiap sudut kamar dari rumah- rumah umat Islam, sehingga tidak sedikit identitas keislaman masyarakat, hanya terlihat dari selembar kartu tanda penduduk, atau berekembanglah dengan istilah "Islam KTP”.

${ }^{1}$ Moh Ali Aziz, Ilmu Dakwah, Cet. 1, (Jakarta: Prenada Media, 2004), 1. 
Serangan- serangan semacam ini, haruslah segera dicegah dengan melakukan perbaikan umat. Dimulai memperbaiki hubungan dengan Alloh, sampai perbaikan hubungan dengan manusia. Menyisihkan waktu untuk agama dan menganjurkan orang lain agar mereka meluangkan waktu untuk berkhidmat dalam penyebaran Islam ini².

Dewasa ini, umat Islam dilanda kemerosotan dari segala segi dan aspek, mereka yang memperhatikan Islam banyak yang mengkhawatirkannya, lalu berusaha dengan berbagai cara untuk memperbaiki keadaan ini, tentu salah satunya dengan berdakwah menegaskan Amar Ma'ruf Nahi Munkar³.

Dakwah adalah suatu kewajiban bagi umat Islam yang beriman kepada Alloh SWT, baik bagi sekelompok orang atau individu yang mengerti, memahami, bahkan mengamalkan ajaran-ajaran Islam.

Dakwah merupakan kegiata syar'i berdasaarkan firman Alloh SWT dalam surah al-Imran/: 104 sebagai berikut:

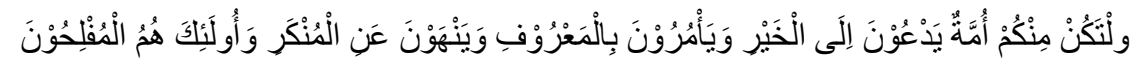

"Dan hendaklah ada di antara kamu segolongan umat yang menyeru kepada kebajikan, menyeru kepada yang ma'ruf dan mencegah dari yang mungkar; merekalah orang-orang yang beruntung (Q.S Al Imran 104). ${ }^{4}$

Penguatan ajaran Islam melalui kegiatan secara berkelompok untuk melawan pemikiranpemikiran yang tidak sesuai dengan ajaran Islam bisa menjadi salah satu solusi yang dapat ditempuh, salah satunya adalah dengan gerakan Jamaah Tabligh.

Jamaah Tabligh adalah himpunan sekelompok yang menyampaikan dan menyiarkan pesan dan ajaran-ajaran Islam, bahakan merupakan gerakan kelompok pengikut yang terbesar dalam upaya menegakkan Amar Ma'ruf Nahi Munkar. ${ }^{5}$

Atas dasar tersebut, dalam upaya meberikan solusi bagi permasalahan yang terjadi di masyarakat, Jamaah Tabligh berusaha untuk menjalankan metode dakwah yang sesuai dengan metode dakwahnya Rasulullah SAW yang di sebut dengan metode dakwah nubuwwah.

Salah satu gerakan dakwah yang secara intensifberperan aktif sampai saat ini dalam menjaga Amar Ma'ruf Nahi Munkar bagi masyarakat dan santri, yaitu Masjid Pakes PP. Darul Ulum Pakes Desa Panaan Kacamatan Palengaan.

Masjid Pakes PP. Darul Ulum Pakes merupakan suatu tempat yang di dalamnya ada faktor penggerak massa untuk memotivasi lingkungan sekitar dengan ajaran-ajaran keagamaan yang

\footnotetext{
${ }^{2}$ Maulana Muhammad Ihtisyamul Hasan al-Kandahlawi, Himpunan Fadhilah Amal, bab satu-satunya cara memperbaiki kemerosotan kaum muslimin, (Yogyakarta: Ash-Shaff, 2006), Cet- ke II, 647.

${ }^{3}$ Maulana Muhammad Ihtisyamul Hasanal-Kandahlawi,Himpunan Fadhilah Amal,bab hadits Rasulullah yang menegaskan Amar Ma'ruf Nahi Mungkar, (Yogyakarta: Ash-Shaff, 2006), Cet- ke II, 386.

${ }^{4} \mathrm{Al}$ - Quran Surat Ali Imran 104, Jakarta Al- Mubin, 63.

${ }^{5}$ H. As'ad Said Ali, www. NU. Or. Id, NU Online, yang di tulis pada hari senin, 13 Juni 2011
} 
benar, terutama dalam menjaga Amar Ma'ruf Nahi Munkar, yaitu apresiasi Jamaah Tabligh. Jamaah Tabligh memegang beberapa hal pokok dalam setiap misi dakwahnya ${ }^{6}$. hal ini menjadi pondasi keyakinan para Jamaah Tabligh untuk mempengaruhi aktifitas kehidupan dan keagamaan sehari-hari terutama menerapkan Amar Ma'ruf Nahi Munkar. Yaitu diantaranya: Pertama, Menerapkan Kalimah agung (syahadat)Laa ilaha Illaallah Muhammmada Rasulullah atau disebut sebagai kalimah Tayyibah. Kedua, Menegakkan shalat Khusu' dan Khudu'. Ketiga adalah Ikromul Muslimin, (Memuliakan dan saling bahu membahu sesama saudara, kerabat, dan tetangga yakni diikat dalam persaudaraan kalimat Laa ilaha Illaallah Muhammmada Rasulullah. Dengan pondasi ini dapat mempengaruhi masyarakat dan santri serta lingkungan dalam menjaga Amar Ma'ruf Nahi Munkar.

Berdasarkan fenomena diatas, maka penulis sangat tertarik untuk melakukan penelitian tentang strategi dakwah Jamaah Tabligh di Masjid Pakes PP. Darul Ulum Pakes Panaan Palengaan Pamekasan kecamatan palengaan kabupaten Pamekasan.

\section{METODE}

Pendekatan yang di gunakan dalam peneltian ini menggunakan pendekatan kualitatif, Pendekatan kualitatif ini dapat menunjukkan pada penelitian tentang kehidupan masyarakat, tingkah laku, juga tentang aktifitas dalam komunitas atau jamaah. Penelitian ini merupakan jenis penelitian kualitatif. Menurut Bogdan, R.C and Taylor,S.J penelitian kualitatif merupakan prosedur penelitian yang menghasilkan data deskriptif berupa kata-kata tertulis atau lisan dari orang-orang dan prilaku yang diamati. ${ }^{7}$

Berdasarkan uraian di atas, maka penelitian kualitatif digunakan jika data yang akan diambil merupakan data yang kualitatif, yaitu yang tersaji dalam bentuk kata-kata ataupun kalimat. Keseluruhan data yang diperoleh, diolah, dan disajikan dalam bentuk uaraian naratif bukan statistik, sehingga dapat menjawab permasalahan yang diteliti secara sistematis dan logis.

Metode yang di gunakan adalah dengan deskriptif analitik. Metode ini adalah dengan mencoba memaparkan atau menggambarkan tentang setrategi dakwah Jamaah Tabligh

Penentuan informen dalam sebuah penelitian merupakan hal yang penting yang harus ditentukan, oleh karena itu peneliti menentukan subjek penelitian diantaranya Pengasuh Pondok Pesantren Darul Ulum Pakes, Jamaah Tabligh, Petugas Bimbingan rohani Pamekasan. Insturmen yang digunakan yang pertama adalah peneliti itu sendiri, karena terjun langsung dalam proses kegiatan yang dilakukan oleh subjek penelitian. Selanjutnya teknik atau prosedur pengumpulan

${ }^{6}$ Nasiri dkk, Kapita Selekta Dakwah, (Surabaya: Koordinatorat perguruan tinggi agama Islam Swasta/Kopertais, 2016) Cet, 1, 168-169.

${ }^{7}$ Muhammad Rusli, Hisyam El Qaderie, Metode Penelitian Kuantitatif dan Kualitatif, (Sumenep : LP3M Paramadani, 2013), hal,170. 
data yang digunakan ada tiga, yaitu wawancara (interview), observasi dan dokumendasi. Pertama Interview atau wawancara adalah percakapan dengan maksud tertentu yang dilakukan oleh dua pihak, yaitu pewawancara (Inteviwer) yang mengajukan pertanyaan dan terwawancara (Interviwee) yang menjawab atas pertanyaan itu. ${ }^{8}$ Sedangkan jenis wawancara yang digunakan dalam penelitian ini adalah wawancara struktur dan tak terstruktur.Wawancara struktur adalah wawancara yang mana pewancaranya menetapkan sendiri masalah dan pertanyaan-pertanyaan yang diajukan dengan tujuan mencari jawaban terhadap hipotesisnya. Sedangkan wawancara takterstrukturdimaksudkan guna menemukan informsi yang bukan baku, seperti pengecualian, penyimpangan, penafsiran yang tidak lazim. Dan pertanyaan yang digunakan dalam wawancara ini tidak disusun terlebihdahulu, akan tetapi disesuaikan dengan keadaan. ${ }^{9}$ Adapun interview yang dimaksud dalam penelitian ini adalah wawancara dengan ketua rombongan (Amir)Jamaah Tabligh, dan takmir Masjid Pakes setempat termasuk ketua atau pengurus Masjid Pakes PP. Darul Ulum Pakes Desa Panaan Kecamatan Palengaan Kabupaten Pamekasan.

Kedua. Observasi. Observasi atau pengamatan adalah alat pengumpulan data yang dilakukan cara mengamati dan mencatat secara sistematik terus menerus melakukan pengamatan atas perilaku seorang. ${ }^{10}$ Jadi, observasi merupakan salah satu metode pengumpulan data yang digunakan untuk memperoleh data-data yang dilakukan secara sengaja baik langsung atau tidak langsung sebagai aktifitas indera terhadap beberapa peristiwa yang berlangsung. dalam proses Observasi Peneliti langsung ingin mendatangi lokasi kegiatan dakwah dengan cara mengikuti aktifitas jamaah agar megnetahui segala bentuk aktifitasnya agar data yang didapatkan maksimal

Ketiga dokumentasi. Dokumentasi adalah mencari data dengan hal-hal atau variable yang berupa catatan, transkip, buku, surat kabar dan sebagainya. ${ }^{11}$

Metode dokumentasi, penulis gunakan atas menyelidiki benda-benda tertulis atau bukti-bukti yang mendukung dan yang dapat memberikan data seperti rekaman kaset, video dan lain sebagainya. Peneliti mengambil data sekunder berupa dokumentasi milik polres pamekasan. Semua dokumentasi di atas, penulis peroleh dengan mendatangi kepala bidang polres pemekasan serta sebagian staf-stafnya yang betul- betul faham dan mengetahui permasalahan tersebut.

Selanjutnya analisis data. Analisis data adalah proses mencari dan menyusun secara sistematis data yang diperoleh dari hasil wawancara, catatan lapangan, dan dokumentasi, dengan cara mengorganisasikan data ke dalam katagori, menjabarkan kedalam unit-unit, melakukan sintesa, menyusun ke dalam pola, memilih mana yang penting dan akan dipelajari, dan membuat

\footnotetext{
${ }^{8}$ Lexy J. Moleong, Metodologi Penelitian Kualitatif, (Bandung, PT. Remaja Rosdakarya, 2008), 186. ${ }^{9}$ Lexy J. Moleong, Metodologi Penelitian Kualitatif, (Bandung, PT. Remaja Rosdakarya), 2008,190.

${ }^{10}$ James A. Black \& Dean J. Champion, Metode Dan Masalah Penelitian Sosial. (Bandung: PT: Refika Aditama 2009), 285.

${ }^{11}$ Muhammad Rusli, Hisyam El Qaderie, Metode Penelitian Kuantitatif dan Kualitatif, (Sumenep : LP3M PARAMADANI, 2013), 126.
} 
kesimpulan sehingga mudah dipahami oleh diri sendiri dan orang lain. ${ }^{12}$ Sesuai dengan sifat dan jenil penelitian ini, yaitu penelitian kualitatif. Untuk menganalisis data yang bersifat kualitatif ini akan digunakan teknik reflektif thinking yaitu dengan mengkombinasikan cara berfikir deduktif dan induktif. Induktif merupakan metode pemikiran yang bertolak belakang dengan hal-hal atau peristiwa yang ada, sedangkan Deduktif merupakan merangkum atau penarikan kesimpulan dari keadaan umum menjadi khusus. Data yang dianalisis yang berkaitan dengan pembahasan di atas, yaitu tentang strategi jamaah tabligh dalam Taskiyat Al Nafs.

Analisis yang digunakan Reduksi data, penyajian data dan penyimpulan data. Pertama, Reduksi Data. Data yang diperoleh dari laporan jumlahnya cukup banyak, untuk itu maka perlu dicatat secara teliti dan rinci. Mereduksi data berarti merangkum, memilih hal-hal pokok, memfokuskan pada hal-hal penting, dicari tema dan polanya. Kedua, Penyajian Data. Penyajian data penelitian kualitatif bisa dilakukan dalam bentuk uraian singkat, bagan, hubungan antar katagori, dan sejenisnya. ${ }^{13}$ Ketiga, Penyimpulan Data Kesimpulan awal yang dikemukakan masih bersifat sementara, dan akan berubah bila ditemukan bukti-bukti yang kuat yang mendukung tahap berikutnya. Tetapi apabila kesimpulan yang dikemukakan pada tahap awal didukung oleh buktibukti yang valid konsisten saat meneliti kembali ke lapangan mengumpulkan data, maka kesimpulan yang dikemukakan merupakan kesimpulan yang kredibel (dipercaya).

\section{HASIL DAN PEMBAHASAN}

Setelah melakukan penelitian peneliti mendapatkan beberapa hasil penelitian sekaligus menjadi pembahasan dalam poin pembahasan ini. Adapun hasil yang dimaksud diantaranya strategi dakwah Jamaah Tabligh dalam Tazkiyat Al-Nafs, Tangangan bagi Jamaah Tabligh, Respon Masyarakat terhadap Jamaah Tabligh dalam menjalankan Dakwahnya dan sulusi dari segala tantangan yang ada. Dari beberapa hasil ini akan dibahas satu persatu sebagai berikut:

\section{a. Strategi dakwah Jamaah Tabligh dalam Tazkiyat Al-Nafs}

Setelah peneliti melaksanakan beberapa tahap dalam penelitiana ini, yaitu wawancara, observasi dan dokumentasi, peneliti mendapatkan bahwa strategi dakwah Jamaah Tabligh adalah sebagai metode, siasat, taktik, atau maniuvers yang di gunakan dalam aktifitas dakwah. ${ }^{14}$

Sedangkan dalam hal ini dalam kegiatan dakwah Jabligh sebagaimana yang telah diuraikan pada bab empat bahwa itu adalah yang dinamakan cara- cara atau adab- adab dakwah Jamaah Tabligh di Masjid Pakes Panaan Palengaan Pamekasan. ${ }^{15}$

\footnotetext{
${ }^{12}$ Sugiyono, Metode Penelitian Pendidikan Pendekatan Kuantitatif, Kualitatif, dan R\&D, (Bandung : Alfabeta, 2009), Cet. IX, 329

${ }^{13}$ Muhammad Rusli, Hisyam El Qaderie, Metode Penelitian Kuantitatif dan Kualitatif, (Sumenep : LP3M Paramadani, 2013), 263-266.

${ }^{14}$ Moh Ali Aziz,Ilmu Dakwah,(Jakarta: Prenadamedia Group, 2016), Cet. Ke- 5,346.

${ }^{15}$ Wawancara dengan Atoillah Salah Satu Anggota Jamaah Tabligh di Masjid Pakes.
} 
Strategi dakwah Jamaah Tabligh di Masjid Pakes PP. Darul Ulum Pakes Panaan Palengaan Pamekasan sebagai berikut;

1. Satrategi dakwah Jamaah Tabligh yang diterapkan selama ini dapat disimpulkan bahwa dalam kegiatan ini teman- teman kelompok dakwah mengajak masyarakat atau Mad'u dengan secara halus, sebab ajakan secara halus adalah cara Rasulullah SAW.

2. Menggunakan dakwahnya menggunakan metode Jaulah(mengujungi/silaturrahmi) ke rumah orang-orang yang dituju.

3. Jaulah satu, maksudnya adalah keliling kekampung untuk mengajak hadir ke masjid, sebelum berangkat Jaulah membentuk kelompok dan berdo'a memohon hidayah kepada Alloh, sesampainya ketempat tujuan menguluk salam dan menyampaiakn maksud serta tujuannnya, para $D a^{\prime} i$ mengajak untuk sama- sama kemasjid agar melaksanakan shalat berjamaah di Msjid sehabis shalat berjamaah maghrib mendengarkan Bayan, dan disitu ada pula yang menjaga masjid tugasnya berdzikir ada pula yang bertugas membolak balikkan sandalnya para tamu kaum berjamaah.

4. Selanjudnya metode Ta'lim Wa ta'allum (belajar-mengajar) pengajian yang dilakukan Jamaah Tabligh di mesjid Pakes, kegiatan Taklim subuh dan dzhuhur. Kegiatan khidmat, kegiatan mudzkaroh dan hal ini kalau di kegiatan Jamaah Tabligh dinakaman Adab Dakwah.

Strategi di atas tidak lepas dari teori yang mengetakan bahwa pengertian strategi dakwah adalah cara atau perencanaan yang berisi rangkaian kegiatan yang didesain untuk mencapai tujuan dakwah tertentu. ${ }^{16}$ Sedangkan Tazkiyat Al- Nafs adalah Secara etimologi kata Tazkiyah mempunyai makna pencucian jiwa. Demikian pula maknanya secara istilah. Tazkiya Al- Nafs artinya penyucian jiwa dari penyakit cacat, merealisasikan (Tahaquq) berbagai maqam padanya, dan menjadikan asma' dn sifat Allah sebagai akhlaknya (Takhaluq). Dengan demikian Tazkiyah adalah tathur, tahaquq, dan takhaluq. ${ }^{17}$ Jadi strategi yang dilakukan oleh Jamaah Tabligh termasuk proses penyucian jiwa dengan cara yang telah dilakukan sesuai dengan uraian di atas.

Adapun respon Masyarakat yang diketahui dari hasil wawancara, Respon masyarakat terhadap dakwah Jamaah Tabligh adalah sangat baik sekali, mengingat masyarakat sudah faham terhadap dakwah dan isi daripada dakwah Jamaah Tabligh, bahkan banyak dari masyarakat yang mempunyai keinginan untuk ikut Khuruj Fi Sabilillah meskipun bukan termasuk anggota Jamaah Tabligh, bahkan dari sebagian masyarakat meskipun dirumahnya banyak kesibukan mereka juga rela meninggalkan pekerjaannya demi ikut keluar/ Khuruj bersama anggota Jamaah Tbligh, dimana tugas pekerjaan rumah seperti mengembala sapi dll, ada yang menanggung untuk merawatnya, asalkan mempunyai niat dan ikut Khuruj bersama anggota Jamaah Tabligh.

\footnotetext{
${ }^{16}$ Asmuni Syukir, Dasar- Dasar Strategi Dakwah Islam,(Surabaya: Al-Ikhlas, 1983), 32

${ }^{17}$ Moh Ali Aziz, Ilmu Dakwah, cet ke-5. (Jakarta: Prenadamedia Group, 2016), 355
} 


\section{b. Tantangan dan Hambatan Dakwah Jamaah Tabligh}

Dakwat tidak lepas dari tantangan atau hambatan yang menimpanya, karena dimana ada kebaikan disitu ada tantangan. Salah satunya seperti yang terjadi pada Jamaah Tabligh di Masjid Pakes sebagai berikut;

1. Faktor pendukung dakwah Jamaah Tabligh di Masjid Pakes.

Melihat data yang telah diperoleh, aktifitas dakwah Jamaah Tabligh di Masjid Pakes terdapat banyak elemen yang mendukung terselenggaranya aktifitas tersebut yang telah direncanakan, seperti dari Jaulah kemasyarakat, khususi, bayanan, mengajak masyarakat shalat berjamaah di Masjid Pakes, yang mana unsur tersebut didukung penuh oleh tokoh masyarakat, para ulama, asatidz serta para masyarakat lebih-lebih para anggota Jamaah Tabligh.

Unsur lain yang mendukung adalah dari anggota jamaah yang keliling kekampung, kerumahrumah mengajak berjamaah yang penuh adab dengan prinsip pokok ikramul muslimin. Santun dalam mengajak. Sehingga masyarakat merasa tertarik.

Selain yang disebutkan di atas terdapat pendukung yang sangat kuat bagi Jamaah tabligh, hal ini dibagi menjadi dua bagian, yaitu faktor intern dan faktor ekstern, faktor intern merupakan faktor dari dalam individu itu sendiri. Sedangkan faktor ekstern itu jelas dari luar yang turut mempengaruhinya. Faktor eks bisa dari keluarga dan masyarakat, apa dan seberapa besar kedua faktor tersebut yang mempengaruhi dakwah Jamaah Tabligh.

\section{Faktor Intern}

Faktor intern (faktor pembawaan), maksudnya bahwa pada diri manusia terdapat fitrah (pembawan) beragama, siapa dan dari manapun datangnya manusia sudah menbawa fitrah beragama atau potensi keimanan pada Tuhan atau pada kekuatan di luar diririnya yang mengatur hidup dan kehidupan. Dan dalam perjalanan kehidupannya, fitrah atau potensi tersebut ada yang berjalan secara alamiah da ada yang mendapat bimbingan dari Nabi dan Rasul Allah SWT.

Adapun dalam dakwah Jamaah Tabligh di Masjid Pakes ini, para anggotanya juga mendapatkan pengaruh dari dalam dirinya sendiri (intern), hal demikianlah yang mempengaruhi perkembangan pemahaman keagamaan dan dakwah islamiah selama mengikuti kegiatn dakwah para Jamaah Tabligh ini, hal demikian dapat diketahui ketika ditanya apa yang mebuat bapak termotivasi untuk mengikuti dakwah Jamaah Tabligh di Masjid Pakes ini? Maka ia menjawab karena ingin mendekatkan diri kepada Allah dan mengamlkan serta menghidupkan Sunnah Nabi Muhammad SAW"18

\section{Faktor Ekstern}

\footnotetext{
${ }^{18}$ Wawancara dengan Syaifullah, salah satu anggota Jamaah Tabligh dan termasuk masyarakat Masjid Pakes. Pada 09 Mei 2019.
} 
Adapun faktor ekstern adalah faktor dari luar diri seorang yang memungkinkannya untuk dapat mengembangkan fitrah beragama dengan sebaik-baiknya, lingkungan yang mempengaruhi perkembangan pemahaman keagamaan anggota dakwah Jamaah Tabligh di Masjid Pakes ini adalah Lingkungan, karena lingkungan yang sangat mempengaruhi perkembangan pemahaman dakwah Jamaah Tabligh. Lingkungan yang dimaksud adalah keluarga. Keluarga merupakan suatu unit sosial terkecil yang terdiri dari orang yang berada dalam suatu ikatan pernikahan yang sekurang-kurangnya terdiri dari ayah dan ibu. hal ini demikian disampaikan oleh bapak Syaifullah ketika ditanya apa motifasi mengikuti Jamaah Tabligh ini, beliau menjawab agar keluarga dapat masuk ke agama yang baik tidak ada gangguan apa-apa, sama-sama faham terhadap dakwah agama, dan saling ikromul muslimin terutama terhadap tetangga

Jadi keluarga juga menjadi faktor yang menjadikan anggota Jamaah Tabligh di Masjid Pakes ini antusias dalam mengikutinya.

2. Faktor penghambat dakwah Jamaah Tabligh di Masjid Pakes

Setelah peneliti menguraikan beberapa faktor pendukung diatas, peneliti melihat adanya faktor penghambat aktifitas dakwah Jamaah Tabligh di Masjid Pakes palengaan pamekasan. Namun, faktor penghambat aktifitas dakwah Jamaah Tabligh tersebut dirasa bukan paktor penghambat yang signifikan. Beberapa faktor penghambat yang peneliti temukan diantaranya:

a) Dikeranakan sering kali ketika pelaksanaan aktifitas dakwah Jamaah Tabligh bentrok dengan kesibukan masyarakat sehingga banyak masyarakat yang tidak mengahdiri acara-acara dakwah di Masjid Pakes.

b) Kurangnya minat masyarakat mengikuti kegiatan-kegiatan yang dilaksanakan di Masjid Pakes, hal tersebut mungkin dikarenakan waktu pelaksanaan kegiatan ada yang terlalu larut malam seperti istighasah dan lain sebagainya.

\section{c. Solusi Dakwah Jamaah Tabligh}

Ada beberapa Solusi dakwah Jamaah Tabligh di Masjid Pakes antara lain: Masyarakat yang berkeinginan Khuruj (keluar) namun sibuk dengan pekerjaan rumah, seperti mengembala sapi dll, maka tugas tersebut di tanggung sebagian anggota Jamaah Tabligh yang kebetulan tidak melaksanakan Khuruj agar dapat melaksanakan Khuruj dan ikut berdakwah serta mengamalkan Sunnah Nabawiyah.

Jika masyarakat tidak siap melaksanakan Khuruj selama 3 hari setiap minggu, tujuh hari setiap bulan dan empat puluh hari setiap tahun dengan beralasan minimnya biaya atau bekal, maka sebagian anggota Jamaah Tabligh dan masyarakat yang minat membantunya siap mendonorkan bekal atau biaya tersebut.

\section{SIMPULAN}


Berdasarkan hasil temuan peneliti menghasilkan kesimpulan pertama Dalam strategi dakwah Jamaah Tabligh dalam Tazkiyat Al- Nafs di Masjid Pakes PP. Darul Ulum Pakes Panaan Pamekasan adalah perumusan segala kegiatan sejak dimulai, sampai berakhirnya kegiatan. Seperti musyawarah, forum perumusan, para petugas Khidmat, petugas Jaulah satu, petugas Taklim pagi, petugas Taklim Dzuhur, petugas Amir Mudzakarah, petugas penyampai adab-adab Jaulah, petugas bayan Ashar, kegiatan Khuruj tiga hari dalam satu minggu dan terakhir petugas bayan Subuh dilakukan secara intensif demi tercapainya jiwa yang bersih atau Tazkiyat Al- Nafs dalam jiwa para masyarakat dan santri.

Kedua. Pendukung dalam menjalankan dakwah dan menjadi minat pada masyarakat karena faktor intern, yaitu memiliki semangat sendiri dan faktor ekstren, memiliki motivasi dari orang lain. Adapun hambatannya karena berbenturan dengan aktifitas lain dan minat masyarakat terkadang lemah.

Ketiga. solusi dakwah Jamaah Tabligh di Masjid Pakes Panaan Palengaan Pamekasan adalah memeberikan solusi pada masyarakat yang tidak bisa ikut Khuruj Fisabilillah dikarenakan bekal atau kesibukan tugas rumah tangga yang tidak mungkin ditinggalakan mereka diharapkan untuk ikut melaksanakan atau mengikuti program dakwah Jamaah Tablighseperti melaksanakan sholat berjamaah lima waktu, mendengarkan bayan dari Amir tentang Ayat- Ayat Allah yang dapat memotifasi giat dalam beribadah dan mengerjakan Sunnah Nabi SAW.

\section{DAFTAR RUJUKAN}

Al- Quran, Jakarta Al- Mubin

Ali Aziz, Moh . Ilmu Dakwah, cet ke-5. (Jakarta: Prenadamedia Group, 2016

Ali Aziz, Moh . Ilmu Dakwah, Cet. 1, (Jakarta: Prenada Media, 2004)

Black, James A. \& Champion, Dean J. Metode Dan Masalah Penelitian Sosial. (Bandung: PT: Refika Aditama 2009)

Moleong, Lexy J. Metodologi Penelitian Kualitatif, (Bandung, PT. Remaja Rosdakarya), 2008

Muhammad Ihtisyamul Hasan al-Kandahlawi, Maulana. Himpunan Fadhilah Amal, bab satusatunya cara memperbaiki kemerosotan kaum muslimin, (Yogyakarta: Ash-Shaff, 2006), Cet- ke II

Muhammad Ihtisyamul Hasanal-Kandahlawi, Maulana . Himpunan Fadhilah Amal,bab hadits Rasulullah yang menegaskan Amar Ma'ruf Nahi Mungkar, (Yogyakarta: Ash-Shaff, 2006), Cet- ke II

Nasiri dkk, Kapita Selekta Dakwah, (Surabaya: Koordinatorat perguruan tinggi agama Islam Swasta/Kopertais, 2016) Cet, 1

Rusli, Muhammad. dan El Qaderie, Hisyam . Metode Penelitian Kuantitatif dan Kualitatif, (Sumenep : LP3M Paramadani, 2013) 
Said Ali, H. As'ad. www. NU. Or. Id, NU Online, yang di tulis pada hari senin, 13 Juni 2011

Sugiyono, Metode Penelitian Pendidikan Pendekatan Kuantitatif, Kualitatif, dan R\&D, (Bandung : Alfabeta, 2009), Cet. IX

Syukir, Asmuni. Dasar- Dasar Strategi Dakwah Islam,(Surabaya: Al-Ikhlas, 1983) 